\title{
Control of Soilborne Pathogens of Zingiber officinale by Methyl lodide and Chloropicrin in China
}

Yuan Li, Lida Chi, Liangang Mao, Dongdong Yan, Zhuanfang Wu, Taotao Ma, Meixia Guo, Qiuxia Wang, Canbin Ouyang, and Aocheng Cao, Department of Pesticides, Key Laboratory of Pesticide Chemistry and Application, State Key Laboratory for Biology of Plant Diseases and Insect Pests, Institute of Plant Protection, Chinese Academy of Agricultural Sciences, Beijing, 100193

\begin{abstract}
Li, Y., Chi, L., Mao, L., Yan, D., Wu, Z., Ma, T., Guo, M., Wang, Q., Ouyang, C., and Cao, A. 2014. Control of soilborne pathogens of Zingiber officinale by methyl iodide and chloropicrin in China. Plant Dis. 98:384-388.

Development of effective alternative soil fumigants is essential to the phasing out of methyl bromide $(\mathrm{MeBr})$ while keeping major soilborne pathogens under control. Here, we report on the laboratory studies and field trials evaluating methyl iodide (MeI) and chloropicrin (Pic) for control of major soilborne ginger (Zingiber officinale) pathogens Ralstonia solanacearum, Pythium spp., Fusarium oxysporum, and Meloidogyne incognita in Shandong province of China. Laboratory studies indicated that MeI at $24 \mathrm{mg} / \mathrm{kg}$ of soil was most effective, reducing four pathogens by $>90 \%$. Treatments with MeI+Pic at $12 \mathrm{mg} / \mathrm{kg}(1: 3$ and 1:5) also reduced these pathogens by $>82 \%$. In the field trials, MeI

at 30 or $40 \mathrm{~g} / \mathrm{m}^{2}$ and MeI+Pic (1:3) at $40 \mathrm{~g} / \mathrm{m}^{2}$ yielded excellent longterm control of all target pathogens. These treatments allowed ginger plants to maintain vigorous growth and produce a greater number of tillers ( $>12$ per plant), and increased ginger yields by $>80 \%$ compared with the nontreated controls. MeI at a reduced rate of $20 \mathrm{~g} / \mathrm{m}^{2}$ or Pic at $40 \mathrm{~g} / \mathrm{m}^{2}$ provided levels of disease control similar to $\mathrm{MeBr}$. These studies demonstrated that injection treatments with MeI at 30 and 40 $\mathrm{g} / \mathrm{m}^{2}$, and MeI+Pic (1:3) at $40 \mathrm{~g} / \mathrm{m}^{2}$, followed by covering with virtually impermeable film, are effective alternatives of soil fumigation for control of the major ginger pathogens in Shandong.
\end{abstract}

Ginger (Zingiber officinale Roscoe) is one of the major commercial crops in Shandong Province, China, where there is a large ginger producer with a long planting history. Owing to successive plantings over many years, soilborne diseases of ginger have become increasingly serious, leading to severe losses in ginger yield and quality. The main soilborne pathogens are Ralstonia solanacearum, Pythium spp., Fusarium oxysporum, and Meloidogyne incognita (19). These diseases are difficult to control. Local farmers often use methyl bromide $(\mathrm{MeBr})$ to disinfest soil prior to planting. Therefore, Shandong is a large consumer of $\mathrm{MeBr}$ in China. However, $\mathrm{MeBr}$ is due to be phased out in developing countries by 1 January 2015 (3). The planned withdrawal of MeBr from use as an agricultural fumigant has prompted a great deal of research to develop economically viable alternatives $(6,22,28,29,35)$.

Among the soil fumigants presented by The Methyl Bromide Technique Option Committee (32) is methyl iodide (MeI). MeI $\left(\mathrm{CH}_{3} \mathrm{I}\right)$ is liquid at room temperature, with a boiling point of $43^{\circ} \mathrm{C}$; it may persist in the atmosphere for 2 to 8 days but degrades by photolysis before reaching the ozone layer. Thus, it is relatively safe for the ozone layer, with an ozone-depleting potential of $0.016 / \mathrm{m}^{3}$, which is $1 / 40$ th that of $\mathrm{MeBr}(10,13,14,32)$. In recent years, many scholars have investigated the use of MeI as a new fumigant for controlling soilborne diseases and insects, as well as its movement in soil (21). Their results indicated that MeI is quite effective for controlling nematodes and Fusarium spp. under laboratory conditions. Some studies have evaluated the application of MeI to strawberry plants (7) and peach trees (9) for control of insect-transmitted diseases. MeI also was used to control $M$. incognita in soils $(2,15)$. Ashworth et al. (1) reported that MeI has been increasingly used as an alternative to $\mathrm{MeBr}$. However, there was no information on MeI for control of soilborne diseases of ginger crops.

Corresponding author: A. Cao, E-mail: caoac@vip.sina.com

Accepted for publication 30 September 2013.

http://dx.doi.org/10.1094/PDIS-06-13-0623-RE

(C) 2014 The American Phytopathological Society
The objective of the present study was to determine the efficacy of MeI alone and in combination with chloropicrin (Pic) as a soil fumigant for control of soilborne pathogens of ginger under laboratory and field conditions.

\section{Materials and Methods}

Two sets of field experiments were conducted during 2010 in two commercial fields in Anqiu, Shandong Province, China. Anqiu has been an important ginger production area in China for more than 15 years but faces problems caused by heavy infestations by root-knot nematodes, soilborne fungi, and bacteria. The fields of study had been severely affected by soilborne diseases, and the yield losses had been particularly severe. The field experiments were accompanied by laboratory studies on the activity of fumigants against soilborne pathogens in ginger-cultivation soils.

Effects of soil fumigation with MeI or Pic in the laboratory assays. Two fumigants-MeI (Beijing Chemical Regents Co., Ltd.) and Pic (Dalian Lvfeng Chemical Co., Ltd.) - were used in this laboratory study. They were evaluated singly and in combination. Treatments included MeI alone at rates of 2, 3, 6, 12, and 24 $\mathrm{mg} / \mathrm{kg}$ of soil; Pic alone at rates of 9 and $10 \mathrm{mg} / \mathrm{kg}$ of soil; MeI+Pic at ratios of $2+10(1: 5)$ and $3+9(1: 3) \mathrm{mg} / \mathrm{kg}$ of soil; plus a nontreated control. Each treatment had three replicates.

Soil samples were collected from the top $20 \mathrm{~cm}$ of a ginger field heavily infested by nematodes and soilborne pathogens in Anqiu. The soil was composed of $59.84 \%$ sand, $37.43 \%$ silt, and $2.73 \%$ clay, with an organic matter content of $12.21 \mathrm{mg} / \mathrm{kg}$ and $\mathrm{pH}$ at 5.42 . The soil was sieved through a $2-\mathrm{mm}$ mesh and then mixed well. The soil moisture was $12.22 \%$ (wt/wt). Particle size analyses were performed using the pipette method (30). Organic carbon contents were determined by wet oxidation, using the method described by Nelson et al. (26). Soil was mixed with $\mathrm{H}_{2} \mathrm{O}$ at a ratio of $1: 2.5$ before the $\mathrm{pH}$ reading was taken. Soil moisture contents were measured by drying to constant mass in an oven at $105 \pm 5^{\circ} \mathrm{C}$ for $5 \mathrm{~min}$.

Approximately $600 \mathrm{~g}$ of soil was placed into each of 301.5 -liter desiccators. After the soils were mixed well in each desiccator, a fumigant was injected into the soil with a pipette and the desiccators were immediately closed with covers. The desiccators were placed in incubators at $25^{\circ} \mathrm{C}$ for 5 days. The desiccators were then opened for a day to release the residual fumigants. 
At the termination of assays, four major soilborne pathogens ( $R$. solanacearum, $F$. oxysporum, Pythium spp., and $M$. incognita) were isolated from the soil and quantified by counting colonies or numbers of individuals, and the fumigation efficacy of MeI and MeI+Pic was subsequently calculated. $R$. solanacearum was isolated from the soil and quantified using triphenyl tetrazolium chloride culture medium (17). F. oxysporum was isolated and quantified using the method of Komada (18), and Pythium spp. were isolated according to Martin's method (23). Root-knot nematodes $M$. incognita were extracted and quantified by centrifugation-based methods, as described by Liu (20). The colonies of $R$. solanacearum, F. oxysporum, and Pythium spp. were counted directly from the agar plates. The dead and live nematodes were counted under a dissecting microscope. A nematode that was not moving was touched lightly with a dissecting needle; if it did not move at all, it was counted as dead; otherwise, counted as living.

Field efficacy trials of MeI and Pic. Two trials (I and II) were carried out in 2010 in Xirulin Village, Linghe Town, Anqiu City, Shandong Province. The trial I site was $2 \mathrm{~km}$ away from the trial II site. The trials were located at latitude $36.25^{\prime}$, longitude $119.12^{\prime}$, which has a temperate climate with a yearly average temperature of $12.2^{\circ} \mathrm{C}$, total precipitation of $646.3 \mathrm{~mm}$, and illumination of $2,502.1 \mathrm{~h}$. The soil texture of the experimental fields was sandy loam with an organic content of $12.21 \mathrm{mg} / \mathrm{kg}, \mathrm{pH} 5.42$, unit weight of $1.50 \mathrm{~g} / \mathrm{cm}^{3}$, and water content of $12.22 \%$. Ginger had been cultivated in both fields for more than 15 years, and both were heavily infested with soilborne pathogens.

$\mathrm{MeI}$ and MeI+Pic were used in both trials. MeBr (Israel Dead Sea Bromine Products Co., Ltd.) was used as a control fumigant. To determine the best dosage of MeI for application, MeI was assessed singly at three rates of 20,30, and 40 $\mathrm{g} / \mathrm{m}^{2}$, and in combination with Pic at two ratios of $1: 5$ and $1: 3$, both mixtures applied at $40 \mathrm{~g} / \mathrm{m}^{2}$. MeBr at $40 \mathrm{~g} / \mathrm{m}^{2}$ and Pic at $40 \mathrm{~g} / \mathrm{m}^{2}$ were used as controls (Table 1 ). Each treatment had three replicates. The same treatments were evaluated in both trials. Each treatment plot area in both experimental fields was $28 \mathrm{~m}^{2}$. All

Table 1. Soil fumigation treatments in field trials

\begin{tabular}{|c|c|c|c|}
\hline Code & Treatment $^{\mathrm{z}}$ & Rate $\left(g / m^{2}\right)$ & Application method \\
\hline 1 & MeI & 20 & Injection \\
\hline 2 & MeI & 30 & Injection \\
\hline 3 & MeI & 40 & Injection \\
\hline 4 & MeI+Pic(1:3) & 40 & Injection \\
\hline 5 & $\mathrm{MeI}+\mathrm{Pic}(1: 5)$ & 40 & Injection \\
\hline 6 & Pic & 40 & Injection \\
\hline 7 & $\mathrm{MeBr}$ & 40 & Hot gas distribution \\
\hline 8 & Control & $\ldots$ & $\ldots$ \\
\hline
\end{tabular}

${ }^{\mathrm{z}} \mathrm{MeI}=$ methyl iodide, $\mathrm{Pic}=$ chloropicrin, and $\mathrm{MeBr}=$ methyl bromide. treatments were covered with virtually impermeable film (VIF) mulch (Bromostop, Bruno Rimini, Ltd.). MeI, MeI+Pic, and Pic treatments were applied by dynamic injection using a small drug delivery machine (Model DJR-202, Dalian Jinmei Soil Disinfection Equipment Development Co., Ltd.). $\mathrm{MeBr}$ was applied by the hot gas method (7). After application of the fumigants, the treated regions were immediately covered with VIF. Nontreated control microplots were cultivated, tamped, and sealed with VIF but received no fumigant. Fumigation treatments started on 17 March 2010, and lasted for 2 weeks.

After 2 weeks of fumigation, the tarp was removed for 1 day and soil samples from the two trials were collected and analyzed in the laboratory. Soil samples were collected from the $0-$ to $20-\mathrm{cm}$ soil layers in each treated and nontreated plot. During the ginger harvest period, soil samples were collected and analyzed once again. Soilborne bacteria, fungi, and nematodes in the sampled soils were determined separately using the same methods described above. $R$. solanacearum, $F$. oxysporum, and Pythium spp. were isolated from the soil and quantified using the methods described by Kelman (17), Komada (18), and Martin (24), respectively. Rootknot nematodes $(M$. incognita) were extracted by centrifugation, based on the methods described by Liu (20).

The ginger transplant time was 20 April 2010. During the ginger growth period, the plots treated by soil fumigation were carefully cultivated to avoid reinfestation from the nontreated control plots. Twenty plants were selected from each plot and the height and tiller number were measured 121 days after planting. During the harvest period, the ginger yield was determined 181 days after planting to evaluate the fumigation effect.

Statistical analyses. The efficacy of treatment with a combination of MeI+Pic was calculated according to the following equation, based on the method described by Colby (4): $E-E_{0}=E-$ $X_{1} X_{2} / 100$, where $E$ is the actual measured efficacy of the combination, $E_{0}$ is the expected efficacy of the combination, $X_{1}$ is the actual measured efficacy of the first fumigant, and $X_{2}$ is the actual measured efficacy of the second fumigant. If $E>E_{0}$, the actions of the combined agents were synergistic; if $E<E_{0}$, the actions of the two agents were antagonistic.

Data were analyzed by analysis of variance using SAS (v. 8.0 for Windows). Differences among means were determined by Fisher's least significant difference test at $P=0.05(5,31)$.

\section{Results}

Effects of soil fumigation with MeI and Pic in the laboratory assays. The effect of MeI on $R$. solanacearum, Pythium spp., $M$. incognita, and $F$. oxysporum is shown in Table 2 . MeI at $2 \mathrm{mg} / \mathrm{kg}$ of soil had low efficacy on four pathogens (35.06 to 59.38\%). At 3 or $6 \mathrm{mg} / \mathrm{kg}$ of soil, MeI demonstrated improved efficacy, with $>82 \%$ against $R$. solanacearum and $M$. incognita and 57.65 to $72.5 \%$ against $F$. oxysporum and Pythium spp. MeI at a concentra-

Table 2. Synergistic control activity of methyl iodide and chloropicrin on four soilborne pathogens of ginger crops ${ }^{\mathrm{x}}$

\begin{tabular}{|c|c|c|c|c|c|c|c|c|c|c|c|c|c|c|c|c|c|}
\hline \multirow[b]{3}{*}{ Treatment $^{y}$} & \multirow[b]{3}{*}{ Rate $^{\mathrm{z}}$} & \multicolumn{16}{|c|}{ Pathogen control (\%) } \\
\hline & & \multicolumn{4}{|c|}{ Ralstonia solanacearum } & \multicolumn{4}{|c|}{ Fusarium oxysporum } & \multicolumn{4}{|c|}{ Pythium spp. } & \multicolumn{4}{|c|}{ Meloidogyne incognita } \\
\hline & & $\boldsymbol{E}$ & $E_{0}$ & $E-E_{0}$ & $\mathbf{C E}$ & $E$ & $E_{0}$ & $E-E_{0}$ & $\mathbf{C E}$ & $\boldsymbol{E}$ & $E_{0}$ & $E-E_{0}$ & CE & $E$ & $E_{0}$ & $E-E_{0}$ & $\mathbf{C E}$ \\
\hline MeI & 2 & 59.38 & $\ldots$ & $\ldots$ & $\ldots$ & 52.5 & $\ldots$ & $\ldots$ & $\ldots$ & 35.06 & $\ldots$ & $\ldots$ & $\ldots$ & 56.4 & $\ldots$ & $\ldots$ & $\ldots$ \\
\hline MeI & 3 & 86.65 & $\ldots$ & $\ldots$ & $\ldots$ & 71.2 & $\ldots$ & $\ldots$ & $\ldots$ & 57.65 & $\ldots$ & $\ldots$ & $\ldots$ & 82 & $\ldots$ & $\ldots$ & $\ldots$ \\
\hline MeI & 6 & 90.83 & $\ldots$ & $\ldots$ & $\ldots$ & 72.5 & $\ldots$ & $\ldots$ & $\ldots$ & 67.01 & $\ldots$ & $\ldots$ & $\ldots$ & 86.1 & $\ldots$ & $\ldots$ & $\ldots$ \\
\hline MeI & 12 & 92.24 & $\ldots$ & $\ldots$ & $\ldots$ & 90.6 & $\ldots$ & $\ldots$ & $\ldots$ & 89.3 & $\ldots$ & $\ldots$ & $\ldots$ & 90.9 & $\ldots$ & $\ldots$ & $\ldots$ \\
\hline MeI & 24 & 97.3 & $\ldots$ & $\ldots$ & $\ldots$ & 92.3 & $\ldots$ & $\ldots$ & $\ldots$ & 90.35 & $\ldots$ & $\ldots$ & $\ldots$ & 92.8 & $\ldots$ & $\ldots$ & $\ldots$ \\
\hline MeI+Pic (1:3) & $3+9$ & 93.44 & 69.42 & 24.02 & + & 92.8 & 54.2 & 38.6 & + & 89.34 & 37.65 & 51.69 & + & 82.7 & 37.9 & 44.73 & + \\
\hline MeI+Pic (1:5) & $2+10$ & 91.85 & 50.28 & 41.57 & + & 91.3 & 41.2 & 50.1 & + & 86.77 & 24 & 62.78 & + & 88.7 & 53.5 & 35.21 & + \\
\hline Pic & 9 & 80.11 & $\ldots$ & $\ldots$ & $\ldots$ & 76 & $\ldots$ & $\ldots$ & $\ldots$ & 65.31 & $\ldots$ & $\ldots$ & $\ldots$ & 65.2 & $\ldots$ & $\ldots$ & $\ldots$ \\
\hline Pic & 10 & 84.67 & $\ldots$ & $\ldots$ & $\ldots$ & 78.5 & $\ldots$ & $\ldots$ & $\ldots$ & 68.44 & $\ldots$ & $\ldots$ & $\ldots$ & 67.3 & $\ldots$ & $\ldots$ & $\ldots$ \\
\hline Control & $\ldots$ & $\ldots$ & $\ldots$ & $\ldots$ & $\ldots$ & $\ldots$ & $\ldots$ & $\ldots$ & $\ldots$ & $\ldots$ & $\ldots$ & $\ldots$ & $\ldots$ & $\ldots$ & $\ldots$ & $\ldots$ & $\ldots$ \\
\hline
\end{tabular}

${ }^{\mathrm{x}} E$ is the actual measured efficacy of the combination, $E_{0}$ was the expected efficacy of the combination, and $\mathrm{CE}=$ combined efficacy. If $E>E_{0}$, the actions of the agents were synergistic; if $E<E_{0}$, the actions of the agents were antagonistic; + means synergistic.

${ }^{\mathrm{y}} \mathrm{MeI}=$ methyl iodide and $\mathrm{Pic}=$ chloropicrin.

${ }^{\mathrm{z}}$ Rate in milligrams per kilogram of soil. 
tion of 12 or $24 \mathrm{mg} / \mathrm{kg}$ of soil showed the best efficacy against all four pathogens $(>89.3 \%)$. Treatment with MeI+Pic (1:3) at 12 $\mathrm{mg} / \mathrm{kg}$ showed a high control efficacy over all the pathogens tested (>88\%), while that of MeI+Pic (1:5) at $12 \mathrm{mg} / \mathrm{kg}$ was $82.7 \%$. Treatments with MeI+Pic (both 1:5 and 1:3) were equally as effective as treatments with MeI alone at 12 or $24 \mathrm{mg} / \mathrm{kg}$ of soil. MeI+Pic combination treatments were more efficacious than either fumigant used alone, indicating a strong synergistic activity. Treatments with Pic at 9 or $10 \mathrm{mg} / \mathrm{kg}$ of soil showed a control effect similar to that of MeI alone at $3 \mathrm{mg} / \mathrm{kg}$ of soil, having an efficacy of $>65 \%$ against the pathogens. There was no significant difference between the effects of the two Pic concentrations. All treatments showed a better control of $R$. solanacearum than on the other three pathogens.

Field efficacy trials of MeI and Pic. Significant control of all four pathogens was observed in all soil fumigation plots immediately after treatments in both field trials, with $\mathrm{MeBr}$ as the best performer (Fig. 1). The results obtained in the two field trials were similar. In trials I and II, all fumigation treatments except MeI at
$20 \mathrm{~g} / \mathrm{m}^{2}$ provided great control of $M$. incognita and $R$. solanacearum. Plots treated with MeI at 30 to $40 \mathrm{~g} / \mathrm{m}^{2}$ and MeI+Pic (1:3) at $40 \mathrm{~g} / \mathrm{m}^{2}$ had significantly lower densities of $R$. solanacearum $(<280 \mathrm{CFU}$ per $10 \mathrm{~g}$ of soil) and $M$. incognita $(<50$ nematodes per $10 \mathrm{~g}$ of soil) compared with the nontreated controls $(>1,700 \mathrm{CFU}$ per $10 \mathrm{~g}$ of soil on $R$. solanacearum and $>300$ nematodes per $10 \mathrm{~g}$ of soil on $M$. incognita). MeI+Pic $(1: 5)$ and Pic at $40 \mathrm{~g} / \mathrm{m}^{2}$ provided a similar level of control.

Likewise, all fumigation treatments reduced the population densities of Pythium spp. and F. oxysporum. MeI at 30 and $40 \mathrm{~g} / \mathrm{m}^{2}$ and MeI+Pic (1:3) at $40 \mathrm{~g} / \mathrm{m}^{2}$ reduced the population densities of Pythium spp. and $F$. oxysporum to $<500 \mathrm{CFU}$ per $10 \mathrm{~g}$ of soil while the nontreated controls had $>1,200 \mathrm{CFU}$ per $10 \mathrm{~g}$ of soil. MeI at $20 \mathrm{~g} / \mathrm{m}^{2}$, MeI+Pic (1:5), and Pic at $40 \mathrm{~g} / \mathrm{m}^{2}$ provided similar levels of control for Pythium spp. and F. oxysporum but less control than $\mathrm{MeBr}$.

This pathogen suppression continued throughout the growing season in both trials, as indicated by soil assays performed at ginger harvest time (Table 3). All treatments reduced $R$. solanacearum

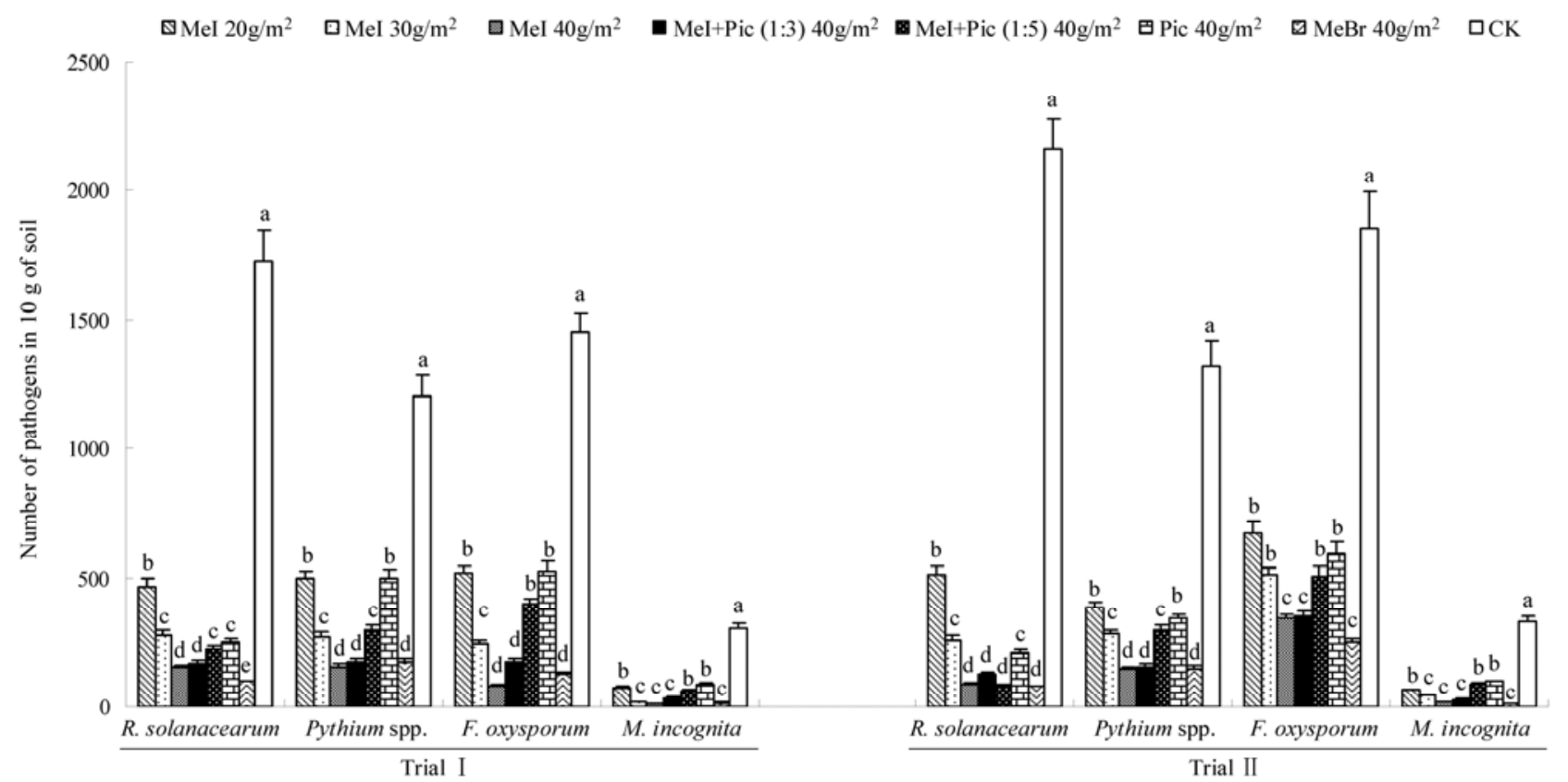

Fig. 1. Recovery of four soilborne pathogens from soil samples collected in the field trials immediately after fumigation treatments. Mel $=$ methyl iodide, Pic $=$ chloropicrin, $\mathrm{MeBr}=$ methyl bromide, and $\mathrm{CK}=$ nontreated control.

Table 3. Effects of soil fumigation on four soilborne pathogens in soil at the ginger harvest ${ }^{\mathrm{y}}$

\begin{tabular}{|c|c|c|c|c|c|c|c|c|}
\hline \multirow[b]{2}{*}{ Treatments $^{\mathrm{z}}$} & \multicolumn{2}{|c|}{ Ralstonia solanacearum } & \multicolumn{2}{|c|}{ Pythium spp. } & \multicolumn{2}{|c|}{ Fusarium oxysporum } & \multicolumn{2}{|c|}{ Meloidogyne incognita } \\
\hline & CFU/g soil & CE (\%) & CFU/g soil & CE (\%) & CFU/g soil & CE (\%) & $N$ & CE (\%) \\
\hline \multicolumn{9}{|l|}{ Trial I } \\
\hline MeI $20 \mathrm{~g} / \mathrm{m}^{2}$ & $490 \mathrm{~b}$ & 76.13 & $527 \mathrm{~b}$ & 60.47 & $544 \mathrm{~b}$ & 61.47 & $81 \mathrm{~b}$ & 63.68 \\
\hline MeI $30 \mathrm{~g} / \mathrm{m}^{2}$ & $302 \mathrm{~b}$ & 85.29 & $299 \mathrm{bc}$ & 77.57 & $267 \mathrm{~cd}$ & 81.82 & $23 \mathrm{c}$ & 89.69 \\
\hline MeI $40 \mathrm{~g} / \mathrm{m}^{2}$ & $286 \mathrm{~b}$ & 86.07 & $255 \mathrm{c}$ & 80.87 & $112 \mathrm{~d}$ & 93 & $20 \mathrm{c}$ & 91.03 \\
\hline MeI+Pic (1:3) $40 \mathrm{~g} / \mathrm{m}^{2}$ & $198 \mathrm{~b}$ & 90.36 & $198 \mathrm{c}$ & 85.15 & $334 \mathrm{c}$ & 77.15 & $40 \mathrm{bc}$ & 82.06 \\
\hline MeI+Pic (1:5) $40 \mathrm{~g} / \mathrm{m}^{2}$ & $247 \mathrm{~b}$ & 87.97 & $322 \mathrm{bc}$ & 75.84 & $422 \mathrm{c}$ & 71.24 & $67 \mathrm{bc}$ & 70.92 \\
\hline Pic $40 \mathrm{~g} / \mathrm{m}^{2}$ & $279 \mathrm{~b}$ & 86.41 & $525 \mathrm{~b}$ & 60.47 & $553 \mathrm{~b}$ & 61.02 & $94 \mathrm{~b}$ & 57.85 \\
\hline $\operatorname{MeBr} 40 \mathrm{~g} / \mathrm{m}^{2}$ & $126 \mathrm{~b}$ & 93.86 & 202 c & 84.85 & $153 \mathrm{~d}$ & 89.65 & $21 \mathrm{c}$ & 90.58 \\
\hline Control & $2,053 \mathrm{a}$ & $\ldots$ & $1,333 \mathrm{a}$ & $\ldots$ & $1,478 \mathrm{a}$ & $\ldots$ & $223 \mathrm{a}$ & $\ldots$ \\
\hline \multicolumn{9}{|l|}{ Trial II } \\
\hline MeI $20 \mathrm{~g} / \mathrm{m}^{2}$ & $531 \mathrm{~b}$ & 76.75 & $401 \mathrm{~b}$ & 60.09 & $893 \mathrm{~b}$ & 62.78 & $69 \mathrm{bc}$ & 71.72 \\
\hline MeI $30 \mathrm{~g} / \mathrm{m}^{2}$ & $279 \mathrm{~b}$ & 87.78 & $301 \mathrm{~b}$ & 70.01 & $534 \mathrm{~b}$ & 77.75 & $48 \mathrm{c}$ & 80.33 \\
\hline MeI $40 \mathrm{~g} / \mathrm{m}^{2}$ & $106 \mathrm{~b}$ & 95.36 & $250 \mathrm{~b}$ & 75.10 & $582 \mathrm{~b}$ & 75.75 & $21 \mathrm{c}$ & 91.39 \\
\hline MeI+Pic (1:3) $40 \mathrm{~g} / \mathrm{m}^{2}$ & $148 \mathrm{~b}$ & 93.52 & $254 \mathrm{~b}$ & 74.70 & $472 \mathrm{~b}$ & 80.33 & $34 \mathrm{c}$ & 86.07 \\
\hline MeI+Pic (1:5) $40 \mathrm{~g} / \mathrm{m}^{2}$ & $104 \mathrm{~b}$ & 95.45 & $320 \mathrm{~b}$ & 68.13 & $526 \mathrm{~b}$ & 78.08 & $91 \mathrm{~b}$ & 62.70 \\
\hline Pic $40 \mathrm{~g} / \mathrm{m}^{2}$ & $229 \mathrm{~b}$ & 89.97 & $361 \mathrm{~b}$ & 64.04 & $615 \mathrm{~b}$ & 74.38 & $102 \mathrm{~b}$ & 58.20 \\
\hline $\mathrm{MeBr} 40 \mathrm{~g} / \mathrm{m}^{2}$ & $99 \mathrm{~b}$ & 95.67 & $251 \mathrm{~b}$ & 75.00 & $471 \mathrm{~b}$ & 80.38 & $19 \mathrm{c}$ & 92.21 \\
\hline Control & $2,284 \mathrm{a}$ & $\ldots$ & $1,004 \mathrm{a}$ & $\ldots$ & $2,400 \mathrm{a}$ & $\ldots$ & $244 \mathrm{a}$ & $\ldots$ \\
\hline
\end{tabular}

${ }^{y}$ In each column, data were the means of three replicates. Means followed by the same letter were not different according to the least significant difference test at $P=0.05$.

${ }^{\mathrm{z}} \mathrm{MeI}=$ methyl iodide, $\mathrm{Pic}=$ chloropicrin, and $\mathrm{MeBr}=$ methyl bromide. 
by $>75 \%$. Similarly, MeI at 30 and $40 \mathrm{~g} / \mathrm{m}^{2}$ and MeI+Pic (1:3) at $40 \mathrm{~g} / \mathrm{m}^{2}$ reduced $F$. oxysporum and Pythium spp. by $>70 \%$, which was similar to results with $\mathrm{MeBr}$. These treatments also reduced nematodes by $>80 \%$, which was slightly less than that achieved with $\mathrm{MeBr}$.

Greater number of tillers, taller plants, and higher ginger yield were observed in all fumigant-treated plots than the nontreated control plots (Tables 4 and 5). Plots treated by $\mathrm{MeBr}$ produced ginger at $99,346.4 \mathrm{~kg} / \mathrm{ha}$ in trial I and $98,947.2 \mathrm{~kg} / \mathrm{ha}$ in trial II, a $90 \%$ yield increase compared with the controls. The plots treated with MeI at 30 and $40 \mathrm{~g} / \mathrm{m}^{2}$ and MeI+Pic (1:3) at $40 \mathrm{~g} / \mathrm{m}^{2}$ had a greater number of tillers, approximately 12 per plant, and resulted in $>80 \%$ of ginger yield compared with those treated with MeI or Pic at other rates. Plots treated with MeI at $20 \mathrm{~g} / \mathrm{m}^{2}$ produced about 10 tillers per plant and ginger at $80,000 \mathrm{~kg} / \mathrm{ha}$, which was still significantly higher than in the nontreated controls.

\section{Discussion}

This study demonstrated that MeI alone and in combination with Pic can effectively control four major soilborne ginger pathogens: $R$. solanacearum, Pythium spp., F. oxysporum, and M. incognita.

In laboratory studies, MeI provided better control of $R$. solanacearum and $M$. incognita while Pic showed better control of $R$. solanacearum and $F$. oxysporum. Treatments with $\mathrm{MeI}$ at different concentrations all showed better control of $R$. solanacearum and $M$. incognita than of $F$. oxysporum and Pythium spp., with their effectiveness depending on the dose used. Our results with the four pathogens and data in other reports $(16,33)$ show that the combination of MeI and Pic has markedly high control efficacy on soilborne pathogens owing to its broader spectrum of activity and synergism between the two compounds. Pic-only treatments showed better efficacy in the control of $R$. solanacearum and $F$. oxysporum than of Pythium spp. and $M$. incognita, probably because Pic is primarily used as a fungicide and is expected to have a greater effect in the control of fungi than of nematodes $(8,12,16,25)$.

Field trials along with the lab studies provided effective alternatives to $\mathrm{MeBr}$ for control of the major soilborne ginger pathogens in Shandong province of China. MeI at 30 and $40 \mathrm{~g} / \mathrm{m}^{2}$ and MeI+Pic (1:3) at $40 \mathrm{~g} / \mathrm{m}^{2}$ provided levels of long-term control similar to $\mathrm{MeBr}$ for soilborne bacteria, fungi, and nematodes. As a result, plants of these treatments maintained vigorous growth, had a greater number of tillers, and increased yield by $>80 \%$ compared with the nontreated control. These results are in agreement with those from previous studies that used MeI+Pic (50:50 mixtures) to control the soilborne pathogen Verticillium dahlia on strawberry (16). MeI at 30 to $40 \mathrm{~g} / \mathrm{m}^{2}$ and MeI+Pic (1:3) at $40 \mathrm{~g} / \mathrm{m}^{2}$ were appropriate dosages for the economic and efficient fumigation of ginger fields. In both field trials, the effectiveness of fumigation was good in the 0 - to $20-\mathrm{cm}$ soil layers, probably owing to high penetration by $\mathrm{MeI}$ and $\mathrm{MeBr}(7,21,32)$. In addition, the odor and eye irritation caused by Pic at very low levels is an effective alert for the presence of this compound and has been used previously for this purpose along with $\mathrm{MeBr}(7,16,24)$. Considering the high cost of MeI and the relatively low cost of Pic, it is also good to use a mixture of MeI and Pic to reduce chemical costs while maintaining high efficacy.

Fumigant injection is a viable method of soil treatment. Duniway et al. (7) reported that MeI is generally applied by conventional shank methods and drip systems $(7,27)$. However, we used the injection method for MeI and MeI+Pic and obtained good field efficacy. In addition, this mechanical injection was simple to implement, saving time, human resources, and cost, and is more suitable for large-scale ginger field fumigation. The volatile and toxic nature of MeI has drawn wide attention because of concerns over potential atmospheric emissions following field fumigation treatment (34). Ashworth et al. (1) reported that surface tarping with VIF would be highly effective as an emission-reduction strategy and would also result in maintenance of high soil gas concentrations (which is important for pest control). In our study, surface tarping with VIF was effective for the control of soilborne pathogens and produced high ginger yields.

In conclusion, this study demonstrated that $\mathrm{MeI}$ at 30 to 40 $\mathrm{g} / \mathrm{m}^{2}$ and MeI+Pic $(1: 3)$ at $40 \mathrm{~g} / \mathrm{m}^{2}$, applied by injection treatment and covered with VIF tarps, are effective alternatives to $\mathrm{MeBr}$ in soil fumigation for ginger production in Shandong province of China.

\section{Acknowledgments}

This research was supported by the National Natural Science Foundation of China (program number 31101462) and the China Methyl Bromide Transition Program (Special Finance of Chinese Ministry of Agriculture, 2110402).

Table 4. Effect of soil fumigation on ginger plant height, tiller number, and yield in trial $\mathrm{I}^{\mathrm{y}}$

\begin{tabular}{|c|c|c|c|c|}
\hline Treatment $^{\mathrm{z}}$ & Plant height $(\mathrm{cm})$ & Tillers/plant & Yield (kg/ha) & Yield increase (\%) \\
\hline MeI $20 \mathrm{~g} / \mathrm{m}^{2}$ & $70.3 \mathrm{~b}$ & $10.1 \mathrm{~b}$ & $86,853.6 \mathrm{ab}$ & 66.55 \\
\hline MeI $30 \mathrm{~g} / \mathrm{m}^{2}$ & $74.7 \mathrm{ab}$ & $12.8 \mathrm{ab}$ & $94,137.5 \mathrm{a}$ & 80.52 \\
\hline MeI $40 \mathrm{~g} / \mathrm{m}^{2}$ & $79.9 \mathrm{a}$ & $15.4 \mathrm{a}$ & $94,428.6 \mathrm{a}$ & 81.08 \\
\hline MeI+Pic (1:3) $40 \mathrm{~g} / \mathrm{m}^{2}$ & $82.7 \mathrm{a}$ & $15.1 \mathrm{a}$ & $95,542.9 \mathrm{a}$ & 83.21 \\
\hline MeI+Pic (1:5) $40 \mathrm{~g} / \mathrm{m}^{2}$ & $78.3 \mathrm{a}$ & $10.3 \mathrm{~b}$ & $80,407.1 \mathrm{~b}$ & 54.19 \\
\hline Pic $40 \mathrm{~g} / \mathrm{m}^{2}$ & $72.4 \mathrm{ab}$ & $10.7 \mathrm{~b}$ & $81,365.1 \mathrm{~b}$ & 56.03 \\
\hline $\mathrm{MeBr} 40 \mathrm{~g} / \mathrm{m}^{2}$ & $80.2 \mathrm{a}$ & $14.9 \mathrm{a}$ & $99,346.4 \mathrm{a}$ & 90.51 \\
\hline Control & $58.3 \mathrm{c}$ & $7.3 \mathrm{c}$ & $52,148.2 \mathrm{c}$ & $\ldots$ \\
\hline
\end{tabular}

${ }^{y}$ In each column, data were the means of three replicates. Means followed by the same letter were not different according to the least significant difference test at $P=0.05$.

${ }^{\mathrm{z}} \mathrm{MeI}=$ methyl iodide, $\mathrm{Pic}=$ chloropicrin, and $\mathrm{MeBr}=$ methyl bromide.

Table 5. Effect of soil fumigation on ginger plant height, tiller number, and yield in trial II ${ }^{\mathrm{y}}$

\begin{tabular}{|c|c|c|c|c|}
\hline Treatment $^{\mathrm{z}}$ & Plant height (cm) & Tillers/plant & Yield (kg/ha) & Yield increase (\%) \\
\hline MeI $20 \mathrm{~g} / \mathrm{m}^{2}$ & $71.2 \mathrm{~b}$ & $10.5 \mathrm{ab}$ & $87,029.7 \mathrm{ab}$ & 69.95 \\
\hline MeI $30 \mathrm{~g} / \mathrm{m}^{2}$ & $71.9 \mathrm{~b}$ & $11.8 \mathrm{ab}$ & $94,418.6$ a & 84.38 \\
\hline MeI $40 \mathrm{~g} / \mathrm{m}^{2}$ & $79.7 \mathrm{a}$ & $12.3 \mathrm{ab}$ & $95,314.5 \mathrm{a}$ & 86.13 \\
\hline MeI+Pic (1:3) $40 \mathrm{~g} / \mathrm{m}^{2}$ & $80.4 \mathrm{a}$ & $14.5 \mathrm{a}$ & $96,718.3 \mathrm{a}$ & 88.87 \\
\hline MeI+Pic (1:5) $40 \mathrm{~g} / \mathrm{m}^{2}$ & $78.0 \mathrm{a}$ & $14.0 \mathrm{a}$ & $82,115.8 \mathrm{~b}$ & 60.36 \\
\hline Pic $40 \mathrm{~g} / \mathrm{m}^{2}$ & $70.3 \mathrm{~b}$ & $10.6 \mathrm{ab}$ & $82,505.4 \mathrm{~b}$ & 61.12 \\
\hline $\mathrm{MeBr} 40 \mathrm{~g} / \mathrm{m}^{2}$ & $79.6 \mathrm{a}$ & $13.9 \mathrm{a}$ & $98,947.2 \mathrm{a}$ & 93.23 \\
\hline Control & $61.2 \mathrm{c}$ & $7.1 \mathrm{~b}$ & $51,207.6 \mathrm{c}$ & $\ldots$ \\
\hline
\end{tabular}

${ }^{y}$ In each column, data were the means of three replicates. Means followed by the same letter were not different according to the least significant difference test at $P=0.05$.

${ }^{\mathrm{z}} \mathrm{MeI}=$ methyl iodide, $\mathrm{Pic}=$ chloropicrin, and $\mathrm{MeBr}=$ methyl bromide. 


\section{Literature Cited}

1. Ashworth, D. J., Luo, L., Xuan, R., and Yates, S. R. 2011. Irrigation, organic matter addition, and tarping as methods of reducing emissions of methyl iodide from agricultural soil. Environ. Sci. Technol. 45:1384-1390.

2. Becker, J. O., Ohr, H. D., Grech, N. M., McGipen, M. E., and Sims, J. J. 1998. Evaluation of methyl iodide as a soil fumigant in container and small field plot studies. Pestic. Sci. 52:58-62.

3. Bell, C. H. 2000. Fumigation in the 21st century. Crop Prot. 19:563-569.

4. Colby, S. R. 1967. Calculating synergistic and antagonistic responses of herbicide combinations. Weeds 15:20-22.

5. Csinos, A. S., Johnson, W. C., Johnson, A. W., Sumner, D. R., McPherson, R. M., and Gitaitis, R. D. 1997. Alternative fumigants for methyl bromide in tobacco and pepper transplant production. Crop Prot. 16:585-594.

6. Desaeger, J. A., Seebold, K. W., and Csinos, A. S. 2008. Effect of application timing and method on efficacy and phytotoxicity of 1,3-D, chloropicrin and metam-sodium combinations in squash plasticulture. Pest Manage. Sci. 64:230-238.

7. Duniway, J. M. 2002. Status of chemical alternatives to methyl bromide for pre-plant fumigation of soil. Phytopathology 92:1337-1343.

8. Duniway, J. M., Gubler, W. D., and Xiao, C. L. 1997. Response of strawberry to some chemical and cultural alternatives to methyl bromide fumigation of soil under California production conditions. Abstract 21 in: Annu. Int. Res. Conf. Methyl Bromide Alternatives and Emissions Reductions.

9. Eayre, C. G., Sims, J. J., Ohr, H. D., and Mackey, B. 2000. Evaluation of methyl iodide for control of peach replant disorder. Plant Dis. 84:11771179.

10. Gan, J., and Yates, S. R. 1996. Degradation and phase partition of methyl iodide in soil. J. Agric. Food Chem. 44:4001-4008.

11. Gilreatha, J. P., Santosa, B. M., Motisa, T. N., Nolingb, J. W., and Mirussoc, J. M. 2005. Methyl bromide alternatives for nematode and Cyperus control in bell pepper (Capsicum annuum). Crop Prot. 24:903-908.

12. Gullino, M. L., Camponogara, A., Gasparrini, G., Rizzo, V., Clini, C., and Garibaldi, A. 2003. Replacing methyl bromide for soil disinfestation: the Italian experience and the implications for other countries. Plant Dis. 87:1012-1021.

13. Guo, M. S., and Gao, S. D. 2009. Degradation of methyl iodide in soil: effects of environmental factors. J. Environ. Qual. 38:513-519.

14. Guo, M. X., Zheng, W., Papiernik, S. K., and Yates, S. R. 2004. Distribution and leaching of methyl iodide in soil following emulated shank and drip application. J. Environ. Qual. 33:2149-2156.

15. Hutchinson, C. M., McGiffen, M. E., Ohr, H. D., Sims, J. J., and Becker, J. O. 1999. Efficacy of methyl iodide soil fumigation for control of Meloidogyne incognita, Tylenchulus semipenetrans and Heterodera schachtii. Nematology 1:407-414

16. Hutchinson, C. M., McGiffen, M. E., Ohr, H. D., Sims, J. J., and Becker, J. O. 2000. Efficacy of methyl iodide and synergy with chloropicrin for control of fungi. Pest Manage. Sci. 56:413-418.

17. Kelman, A. 1954. The relationship of pathogenicity in Pseudomonas solanacearum to colony appearance on a tetrazolium medium. Phytopathology 44:693-695.

18. Komada, H. 1975. A semi-selective media described by Komada will be used for Fusaria detection-development of selective medium for quantitative isolation of Fusarium oxysporum from natural soil. Rev. Plant Prot. Res. 8:114-125.

19. Li, Y., Chi, L. D., Mao, L. G., Yan, D. D., Wu, Z. F., Ma, T. T., Guo, M. X., Wang, Q. X., Ouyang, C. B., and Cao, A. C. 2013. First report of ginger rhizome rot caused by Fusarium oxysporum in China. Plant Dis. http:// dx.doi.org/10.1094/PDIS-07-13-0729-PDN

20. Liu, W. 2000. Plant Pathogenic Nematodes. China Agriculture Press, Beijing.

21. Luo, L., Ashworth, D., Dungan, R. S., Xuan, R., and Yates, S. R. 2010. Transport and fate of methyl iodide and its pest control in soils. Environ. Sci. Technol. 44:6275-6280.

22. Mao, L. G., Wang, Q. X, Yan, D. D., Xie, H. W., Li, Y, Guo, M. X., and Cao, A. C. 2012. Evaluation of the combination of 1,3-dichloropropene and dazomet as an efficient alternative to methyl bromide for cucumber production in China. Pest Manage. Sci. 68:602-609.

23. Martin, F. N. 1992. The genus Pythium. Pages 39-49 in: Methods for Research on Soilborne Phytopathogenic Fungi. L. L. Singleton, J. D. Mihail, and C. M. Rush, eds. American Phytopathological Society, St. Paul, MN.

24. Martin, F. N. 2003. Development of alternative strategies for management of soilborne pathogens currently controlled with methyl bromide. Annu. Rev. Phytopathol. 41:325-350.

25. Minuto, A., Gullino, M. L., Lamberti, F. D., Addabbo, T., Tescari, E., Ajwa H., and Garibaldi, A. 2006. Application of an emulsifiable mixture of 1,3dichloropropene and chloropicrin against root knot nematodes and soilborne fungi for greenhouse tomatoes in Italy. Crop Prot. 25:1244-1252.

26. Nelson, D. W., and Sommers, L. E. 1985. Total carbon, organic carbon andorganic matter. Pages 539-576 in: Methods of Soil Analysis. A. L. Page, R. H. Miller, and O. R. Keency, eds. American Society of Agronomy Publishers, Madison, WI

27. Ohr, H. D., Sims, J. J., Grech, N. M., Becker, J. O., and McGiffen, M. E. 1996. Methyl iodide, an ozone-safe alternative to methyl bromide as a soil fumigant. Plant Dis. 80:731-735.

28. Qiao, K., Jiang, L., Wang, H., Ji, X., and Wang, K. 2010. Evaluation of 1,3dichloropropene as a methyl bromide alternative in tomato crops in China. J. Agric. Food Chem. 58:395-399.

29. Ruzo, L. O. 2006. Review: physical, chemical and environmental properties of selected chemical alternatives for the pre-plant use of methyl bromide as soil fumigant. Pest Manage. Sci. 62:99-113.

30. Schinner, F. O., Hlinger, R., Kandeler, E., and Margesin, R. 1995. Pages 386-389 in: Methods in Soil Biology. Springer-Verlag, Berlin/Heidelberg, Germany.

31. Steel, R. G. D., and Torrie, J. H. 1960. Principles and Procedures of Statistics. McGraw-Hill Book Co., Inc., New York.

32. UNEP, MBTOC. 2002. Pages 43-60 in: Report of the Methyl Bromide Technical Options Committee. UNEP, Nairobi, Kenya.

33. Wilhelm, S., and Paulus, A. O. 1980. How soil fumigation benefits the California strawberry industry. Plant Dis. 64:264-270.

34. Yates, S. R., Gan, J., Papiernik, S. K., Dungan, R. S., and Wang, D. 2002. Reducing fumigant emissions after soil application. Phytopathology 92:1344-1348.

35. Zheng, W., Yates, S. R., Guo, M. X., Papiernik, S. K., and Kim, J. H. 2004 Transformation of chloropicrin and 1,3-dichloropropene by metam sodium in a combined application of fumigants. J. Agric. Food Chem. 52:3002-3009. 